\title{
PENGEMBANGAN MODUL SISTEM PERTIDAKSAMAAN DUA VARIABEL BERBASIS GEOGEBRA TERHADAP KEMAMPUAN VISUAL THINKING MATEMATIS SISWA KELAS $X$
}

\author{
Nailul Himmi*, Lia Bidari Agustin Hatwin** \\ Program Studi Pendidikan Matematika, Fakultas Keguruan dan Ilmu Pendidikan, \\ Universitas Riau Kepulauan, Batam, Kepulauan Riau \\ e-mail: $\underline{\text { nailul.hsb@gmail.com; }}$ ** liabidari24@gmail.com
}

\begin{abstract}
Abstrak. Penelitian pengembangan ini bertujuan untuk membuat bahan ajar matematika berupa modul pada materi sistem pertidaksamaan dua variabel berbasis GeoGebra terhadap kemampuan visual thinking matematis siswa SMA kelas X, serta mengetahui kualitas bahan ajar ditinjau dari kevalidan, kepraktisan, dan keefektifan. Pengembangan modul dilakukan berdasarkan model ADDIE dengan tahapan analisis, desain, development, implementation, dan evaluation. Instrumen yang digunakan berupa lembar penilaian modul untuk ahli materi dan ahli media untuk mengukur kevalidan, angket respon siswa untuk mengukur kepraktisan, serta soal tes visual thinking untuk mengukur keefektifan media. Uji coba produk dilakukan sebanyak 3 kali di SMA Negeri 8 Batam pada kelas X MIPA 5 yang mengimplementasikan Kurikulum 2013. Hasil penelitian ini berupa modul sistem pertidaksamaan dua variabel berbasis GeoGebra terhadap kemampuan visual thinking matematis siswa SMA kelas X. Berdasarkan hasil penelitian diperoleh bahwa modul dikatakan sangat valid $(3,46)$, praktis $(3,04)$ dan efektif $(89 \%)$, serta kemampuan visual thinking matematis siswa dengan rata-rata kelas 89,61 .
\end{abstract}

Kata Kunci: Modul, visual thinking, dan Geogebra

\begin{abstract}
This development research aims to create mathematics teaching materials in the form of modules on the material of the system of in equality of two variables based on GeoGebra on mathematical visual thinking ability of high school students of class $\mathrm{X}$, and to know the quality of teaching materials in terms of validity, practicality and effectiveness. The module development is based on the ADDIE model with the stages of analysis, design, development, implementation, and evaluation. Instruments used in the form of a module assessment sheet for material experts and media experts to measure validity, questionnaire responses to students to measure practicality, as well as visual thinking test to measure the effectiveness of the media. Trial of the product is done 3 times in SMA Negeri 8 Batam in class X MIPA 5 which implements Curriculum 2013. The result of this research is a modulation system of inequality of two variables based on GeoGebra to visual thinking ability mathematically high school students of class X. Based on the research results obtained that the module is said Excellent (3.46), practical (3.04) and effective (89\%), as well as students mathematical visual thinking ability with grade average of 89,61 .
\end{abstract}

Keyword: Module, visual thinking, and GeoGebra.

\section{Pendahuluan}

Matematika adalah salah satu mata pelajaran yang wajib diajarkan di sekolah di semua jenjang pendidikan dari bangku tingkat dasar hingga perguruan tinggi. Matematika diajarkan sejak dini karena hakikat mata pelajaran matematika, yakni untuk membekali siswa dengan kemampuan berpikir logis, analitis, sistematis, kritis, dan kreatif, serta kemampuan bekerja sama. Kompetensi tersebut diperlukan agar siswa dapat memiliki kemampuan memperoleh, mengelola, dan memanfaatkan informasi untuk bertahan pada keadaan yang selalu berubah, tidak pasti, dan kompetitif. 
Salah satu cabang matematika yang diajarkan di bangku sekolah, dari sekolah dasar hingga sekolah menengah adalah aljabar dan geometri. Aljabar dan geometri merupakan materi yang berbeda tapi kedua materi tersebut sangat saling berhubungan "Approximate and interpret rates of change from graphical and numerical data" dimana beberapa kemampuan aljabar yang harus dimiliki siswa kelas 9-12 salah satunya adalah mampu memperkirakan dan menginterpretasikan nilai dari data grafik dan data numerik. Berdasarkan kemampuan aljabar di atas, dijelaskan bahwa dalam menyelesaikan bentuk persamaan dan pertidaksamaan dapat menggunakan grafik. Menyelesaikan menggunakan grafik merupakan salah satu pendekatan untuk pemecahan masalah dalam geometri yang dipandang dari sudut matematika. Empat kemampuan geometri yang harus dimiliki siswa kelas 9-12 salah satunya adalah menggunakan visualisasi, penalaran spasial, dan model geometri untuk memecahkan masalah. Berdasarkan penjelasan tersebut, setidaknya kemampuan yang harus dimiliki oleh siswa dalam pembelajaran geometri adalah kemampuan visual thinking (NCTM, 2000).

Kemampuan visual thinking berperan untuk memecahkan masalah dari soal-soal yang membutuhkan penalaran tingkat tinggi (Ismi \& Hidayatulloh, 2012). Selanjutnya visual thinking memegang peran penting dalam keberhasilan pembelajaran geometri sebab siswa yang belajar tanpa menggunakan kemampuan visual thinking rawan mengalami miskonsepsi. Sering dijumpai siswa yang memahami rumus secara terpisah dengan objek geometrinya. Akibatnya siswa hanya menghafal rumus tanpa mengetahui kaitannya dengan objek geometrinya. Jika kemampuan untuk memecahkan masalah adalah jantung dari matematika, maka visualisasi merupakan inti pemecahan masalah matematika. Menurut (Guzman, 2002) visualisasi merupakan aspek paling penting dalam matematika, tidak hanya geometri atau yang berhubungan dengan aspek keruangan, tetapi juga aspek lain seperti analitis matematis. Dari pernyataan di atas dapat disimpulkan bahwa visual thinking adalah kemampuan untuk memvisualisasikan suatu rumusan geometri yang berhubungan dengan aspek keruangan dan analisis matematis.

Memvisualisasikan suatu situasi atau objek melibatkan "Memanipulasi mental berbagai altenatif untuk memecahkan masalah yang berkaitan dengan suatu situasi atau objek tanpa manfaat manipulatif kongkrit berdasarkan (MOE, 2016). Visualisasi dapat menjadi alat kognitif yang kuat dalam masalah pemecahan matematis hal ini ditandai sebagai keterampilan yang penting dalam pembelajaran dan penerapan matematika. Visualisasi yang dilakukan oleh siswa melewati proses berikut ketika memecahkan masalah matematika ((MOE, 2016),(Surya, 2012)) 1) Memahami hubungan unsur-unsur spasial (keruangan) dalam masalah; 2) Keterkaitan satu sama lain kepemecahan masalah; 3) Mengkonstruksi atau membangun sebuah representasi visual (dalam pikiran, pada kertas, atau melalui penggunaan alat-alat teknologi); 4) Menggunakan representasi visual untuk memecahkan masalah; 5) Encoding jawaban atas masalah. Selanjutnya (Mohler, 2010) mengatakan ada dua kemampuan visual thinking, yaitu (1) kemampuan untuk memecahkan konten ruang figural yang kompleks; dan (2) kemampuan dalam memanipulasi pola visual, seperti yang ditunjukkan oleh tingkat kesulitan dan kompleksitas pada materi stimulus visual yang bisa ditangani sukses, tanpa memperhatikan kecepatan solusi tugas.

Kemudian adapun karakteristik dari visual thinking yang diadopsi dari tahapan berfikir Van Hiel dalam (Kania, 2016) adalah sebagai berikut; (1) Siswa mengidentifikasi bangun geometri berdasarkan penampakannya secara utuh: (a) gambar sederhana, diagram atau 
seperangkat guntingan dalam posisi yang berbeda; (b) bentuk dan konfigurasi lain yang lebih kompleks; (2) Siswa melukis, menggambar, atau menjiplak bangun geometri; (3) Secara verbal, siswa mendeskripsikan bangun geometri dengan penampakannya secara utuh; (4) Siswa menyelesaikan soal rutin dengan mengoprasikan (menerapkan) pada bangun geometri dengan tidak menggunakan sifat-sifat yang diterapkan secara umum; (5) Siswa mengidentifikasi bagian-bagian bangun geometri. Maka berdasarkan pemaparan dari dua ahli di atas, diambil indikator visual thinking yaitu; (1) Siswa mengidentifikasi bangun geometri berdasarkan penampakannya secara utuh; (2) Siswa melukis, menggambar, atau menjiplak bangun geometri; (3) Secara verbal, siswa mendeskripsikan bangun geometri dengan penampakannya secara utuh; 4) Mengkonstruksi atau membangun sebuah representasi visual (dalam pikiran, pada kertas, atau melalui penggunaan alat-alat teknologi).

Berdasarkan hasil observasi yang dilakukan peneliti dengan memberikan tes awal berupa essay test diperoleh bahwa kemampuan visual thinking siswa di SMA NEGERI 8 BATAM kelas X MIPA 5 tergolong rendah seperti dilampirkan pada tabel 1 berikut:

Tabel 1. Data Hasil Observasi X MIPA 5

\begin{tabular}{clc}
\hline No & \multicolumn{1}{c}{ Indikator Visual thinking } & Nilai Rata-Rata \\
\hline 1 & $\begin{array}{l}\text { Secara verbal, siswa mendeskripsikan bangun geometri } \\
\text { dengan penampakannya secara utuh }\end{array}$ & 2,42 \\
2 & $\begin{array}{l}\text { Siswa mengidentifikasi bangun geometri berdasarkan } \\
\text { penampakannya secara utuh, yaitu bentuk dan konfigurasi } \\
\text { lain yang lebih kompleks }\end{array}$ & 1,13 \\
\hline & Rata-rata kelas & 3,55 \\
\hline
\end{tabular}

Menurut data tersebut dibuktikan bahwa dari 38 orang siswa memiliki kemampuan visual thinking rendah dengan rata-rata, yaitu 3,55 dari nilai max 8. Sebagian besar siswa $\mathrm{X}$ MIPA 5 keliru pada indikator pertama, yaitu pada soal mencari keliling terbesar. Sebanyak 65,8\% siswa menjawab lingkaran A; 23,6\% siswa menjawab lingkaran B; dan sebanyak $10,5 \%$ siswa menjawab lingkaran C. Jawaban yang benar dari soal mencari keliling lingkaran terbesar adalah lingkaran B. Salah satu kesalahan yang terjadi dapat dilihat gambar 1 di bawah ini.
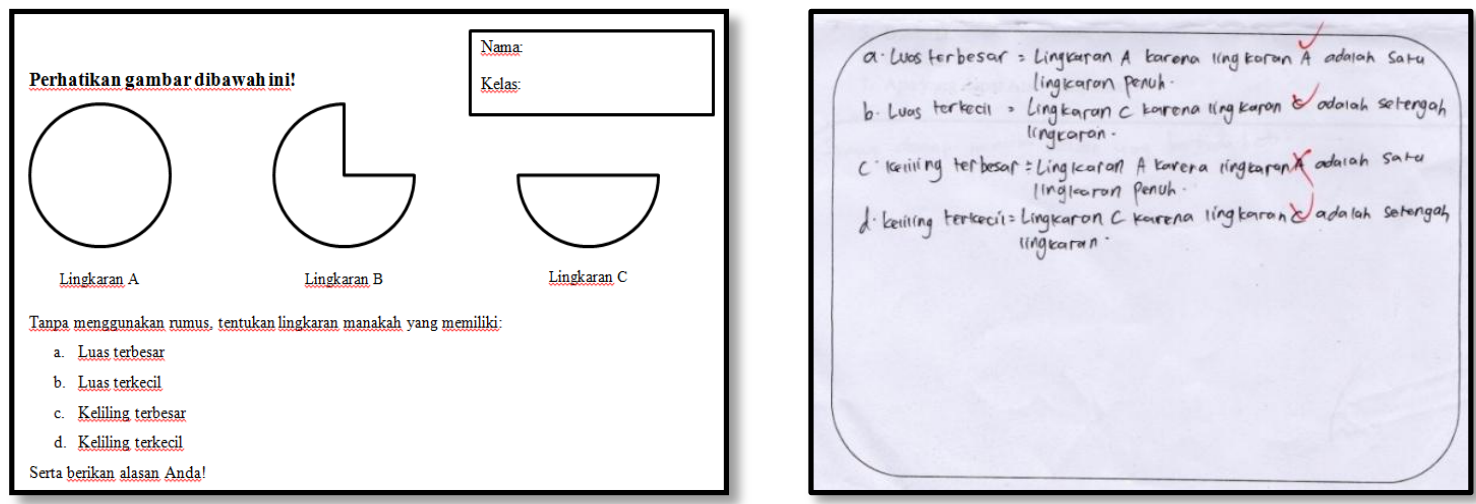

Gambar 1. Soal dan Jawaban salah satu siswa 
Gambar 1 menunjukkan kesalahan siswa pada menghitung keliling terbesar. Sebagaimana objek-objek matematika lainnya, objek geometri juga bersifat abstrak sehingga menuntut siswa untuk mampu membayangkan hal-hal yang tidak jelas bentuk fisiknya (tidak nyata). Hal tersebut berpotensi memunculkan berbagai kesulitan dalam mempelajarinya, terutama bagi siswa di tingkat rendah yang pada umumnya belum mampu berpikir secara abstrak. Fakta demikian mendorong perlunya media pembelajaran yang dapat memberikan pengalaman visual kepada siswa dalam berinteraksi dengan objek-objek geometri yang bersifat abstrak tersebut. Hal ini diperkuat oleh pendapat Dale (Kania, 2016) bahwa pengetahuan akan semakin abstrak apabila hanya disampaikan melalui bahasa verbal. Salah satu solusi permasalahan di atas adalah dengan penggunaan media pembelajaran yang dapat menginterpretasikan konsep matematika tersebut menjadi lebih konkret. Salah satu media pembelajaran yang saat ini telah berkembang demikian pesat adalah menggunakan komputer dengan berbagai program-program yang relevan. Salah satu program komputer yang dapat dimanfaatkan sebagai media pembelajaran matematika adalah program GeoGebra.

GeoGebra adalah sebuah pilihan yang tepat untuk berbagai macam presentasi dari objek matematika karena GeoGebra adalah program geometri dinamis yang membantu membentuk titik, garis, dan semua bentuk lengkungan. Menurut Mahmudi (Asngari, Keguruan, \& Unila, 2015) melalui GeoGebra objek-objek geometri yang bersifat abstrak dapat divisualisasi sekaligus dapat dimanipulasi secara cepat, akurat, dan efisien. Menurut (Himmi, 2016) Penggunaan geogebra dapat dimanfaatkan untuk mendukung proses-proses tersebut karena fitur yang disediakan oleh geogebra sudah cukup lengkap tinggal bagaimana guru dapat membuat media serta meramunya. GeoGebra sangat bermanfaat sebagai media pembelajaran matematika dengan beragam aktivitas sebagai berikut: 1) sebagai media demonstrasi dan visualisasi; 2) sebgai alat bantu konstuksi; 3) sebagai alat bantu proses penemuan (Hohenwarter, 2004).

Salah satu materi matematika yang dapat menggunakan GeoGebra adalah sistem pertidaksamaan dua variabel. Berdasarkan data laporan hasil ujian nasional SMA 2014 dari Kemendikbud daya serap cakupan materi matematika terdiri atas tujuh kompetensi. Capaian salah satu kompetensi yang mengalami penurunan cukup tinggi dari tahun 2011/2012 ke tahun 2012/2013 adalah kompetensi "Fungsi persamaan dan pertidaksamaan," yang juga turun daya serapnya dari $81,86 \%$ menjadi $60,89 \%$, selanjutnya daya serap pada tahun 2014/2015 menjadi 57,28\% (Pendidikan, 2015)

Permasalahan yang terjadi di lingkungan sekolah tak hanya kesulitan siswa dalam memahami pembelajaran melainkan masalah di luar diri siswa. Salah satu contohnya adalah buku teks pelajaran yang disediakan oleh sekolah. Pada materi sistem pertidaksamaan dua variabel tidak termuat dalam buku bantuan operasional sekolah atau biasa disebut buku BOS. Sementara sistem pertidaksamaan dua variabel merupakan salah satu kompetensi dasar yang wajib dipelajari berdasarkan Permendikbud RI no 24 tahun 2016. Sehingga siswa tidak dapat mengontruksikan pengetahuan nya secara mandiri dirumah.

Oleh karena itu, peneliti tertarik untuk mengembangkan bahan ajar pada materi sistem pertidaksamaan dua variabel. Bahan ajar yang dikembangkan berupa modul dengan berbantuan program GeoGebra. Dengan demikian peneliti melakukan penelitian dengan judul "Pengembangan Modul Sistem Pertidaksamaan Dua Variabel Berbasis GeoGebra Terhadap Kemampuan Visual thinking Matematis Siswa Kelas X SMA Negeri 8 Batam”. 


\section{Metode Penelitian}

Jenis penelitian ini adalah penelitian R\&D (Research and Development). Menurut (Sugiyono, 2016) penelitian dan pengembangan berfungsi untuk mengembangkan produk. Mengembangkan produk dalam arti yang luas dapat berupa memperbarui produk yang telah ada. Desain penelitian yang digunakan dalam penelitian ini adalah model pengembangan ADDIE yang terdiri dari lima tahap, yaitu Analysis, Design, Development, Implementation, dan Evaluation. Model pengembangan ini secara sistematis pada gambar 2:

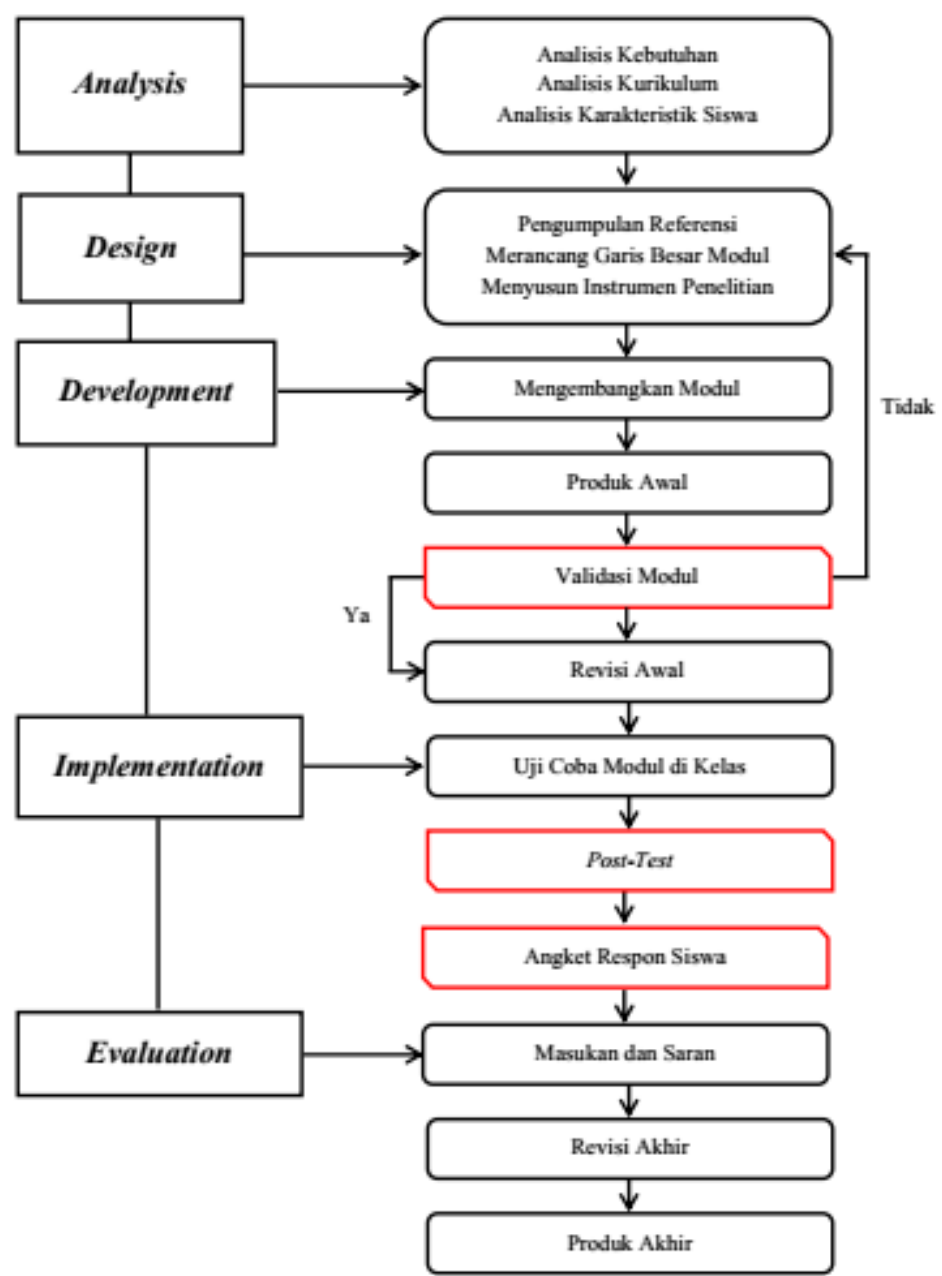

Gambar 2. Tahap Pengembangan dalam mengembangkan bahan Ajar

Gambar 2 dengan kotak merah menunjukkan langkah untuk mengukur tingkat valid, efektif dan efisien dari modul yang dikembangkan. Tempat penelitian dilaksanakan di SMA Negeri 8 Batam, dan waktu penelitian dilaksanakan pada bulan Agustus sampai November 2017. Subjek penelitian ini adalah siswa kelas X MIPA 5 sebanyak 38 orang. Instrumen penelitian yaitu menggunakan lembar validasi modul untuk mengukur kevalidan modul, tes visual thinking untuk mengukur keefektifan modul, dan angket respon siswa untuk mengukur kepraktisan modul. 


\section{Analisis kevalidan Modul}

Menghitung skor rata-rata untuk tiap aspek penilaian dari seluruh validator dengan menggunakan rumus

$$
\bar{x}=\frac{1}{\text { banyak validator }} x \frac{\sum x}{n}
$$

(Astika, 2014)

Keterangan:

$\begin{array}{ll}\bar{x} & : \text { Skor rata-rata } \\ n & : \text { banyak butir pertanyaan } \\ \sum x & : \text { jumlah skor yang di peroleh }\end{array}$

Skor rata-rata yang diperoleh kemudian dikonversikan menjadi data kualitatif, dengan skor maksimal ideal (4) dan skor minimal idela (1), yang disajikan pada tabel 2.

Tabel 2. Konversi data kualitatif menjadi kriteria validitas

\begin{tabular}{cccc}
\hline Rentang Skor konversi kualitatif & Rentang Skor Validitas & Nilai & Kriteria \\
\hline $\bar{x}>M_{i}+1,8 S B_{i}$ & $\bar{x}>3,4$ & $\mathrm{~A}$ & sangat valid \\
$M_{i}+0,6<S B_{i} * \bar{x} \leq M_{i}+1,8 S B_{i}$ & $2,8<\bar{x} \leq 3,4$ & $\mathrm{~B}$ & Valid \\
$M_{i}-0,6<S B_{i} * \bar{x} \leq M_{i}+0,6 S B_{i}$ & $2,2<\bar{x} \leq 2,8$ & $\mathrm{C}$ & cukup valid \\
$M_{i}-1,8<S B_{i} * \bar{x} \leq M_{i}-0,6 S B_{i}$ & $1,6<\bar{x} \leq 2,2$ & $\mathrm{D}$ & kurang valid \\
$\bar{x} \leq M_{i}-1,8 S B_{i}$ & $\bar{x} \leq 1,6$ & $\mathrm{E}$ & tidak valid \\
\hline & & & (Widoyoko, 2017)
\end{tabular}

Keterangan:

$\bar{x} \quad=$ Skor rata-rata

$\mathrm{M}_{\mathrm{i}} \quad=\frac{1}{2}($ Skor maksimal ideal + Skor minimal ideal $)$

$\mathrm{SB}_{\mathrm{i}} \quad=\frac{1}{6}($ Skor maksimal ideal - Skor minimal ideal $)$

Skor maksimal ideal $\quad=$ skor tertinggi

Skor minimal ideal $\quad=$ skor terendah

Modul yang dikembangkan dinyatakan memiliki derajat validitas yang baik jika minimal tingkat validitas yang dicapai adalah katagori valid.

\section{Analisis keefektifan Modul}

Keefektifan modul dianalisis dari data kemampuan visual thinking yang dihitung nilai ketuntasan klasiskalnya dengan menggunakan rumus berikut (Hutagalung, 2017):

$$
P R S=\frac{\sum A}{\sum B} \times 100 \%
$$

Ket: PRS $=$ Persentase keefektifan siswa; $\sum A$ : Proporsi siswa yang memilih; $\sum B:$ Jumlah siswa Tabel 3. Kriteria Ketuntasan Visual thinking

\begin{tabular}{cc}
\hline Persentase \% & Katagori \\
\hline$p>80$ & Sangat baik \\
$60<p \leq 80$ & Baik \\
$40<p \leq 60$ & Cukup baik \\
$20<p \leq 40$ & Kurang baik \\
$p \leq 20$ & Tidak baik \\
\hline & (Widoyoko, 2017)
\end{tabular}




\section{Analisis Keparaktisan Modul}

Aspek kepraktisan modul yang dikembangkan dilihat dari hasil analisis angket respon siswa. Angket respon siswa berbentuk check-list dengan menggunakan skala Likert yang terdiri dari empat kategori yaitu sangat setuju (SS: 4), setuju (S: 3), tidak setuju (TS: 2), dan sangat tidak setuju (STS: 1), yang kemudian dihitung rerata kualitatifnya dan dikonversikan seperti tabel 4 berikut.

Tabel 4. Konversi data kualitatif menjadi kriteria respon siswa

\begin{tabular}{cccc}
\hline Rentang Skor Konversi Kualitatif & Rentang Skor Validitas & Nilai & Kriteria \\
\hline $\bar{x}>M_{i}+1,8 S B_{i}$ & $\bar{x}>3,4$ & A & Sangat Baik \\
$M_{i}+0,6<S B_{i} * \bar{x} \leq M_{i}+1,8 S B_{i}$ & $2,8<\bar{x} \leq 3,4$ & B & Baik \\
$M_{i}-0,6<S B_{i} * \bar{x} \leq M_{i}+0,6 S B_{i}$ & $2,2<\bar{x} \leq 2,8$ & C & Cukup Baik \\
$M_{i}-1,8<S B_{i} * \bar{x} \leq M_{i}-0,6 S B_{i}$ & $1,6<\bar{x} \leq 2,2$ & D & Kurang Baik \\
$\bar{x} \leq M_{i}-1,8 S B_{i}$ & $\bar{x} \leq 1,6$ & E & Tidak Baik \\
\hline & & & (Widoyoko, 2017)
\end{tabular}

\section{Hasil Penelitian dan Pembahasan}

Berdasarkan model pengembangan ADDIE, langkah-langkah pengembangan modul berbasis GeoGebra pada materi sistem pertidaksamaan dua variabel untuk siswa kelas $\mathrm{X}$ dilakukan melalui tahapan berikut.

\section{Tahap Analysis (Analisis)}

Tahap analysis (analisis) dalam penelitian ini meliputi analisis kebutuhan, analisis kurikulum, dan analisis karakteristik siswa.

\section{a. Analisis Kebutuhan}

Hasil analisis ini diperoleh melalui observasi maupun wawancara. Berdasarkan hasil observasi maupun wawancara yang dilakukan kepada seorang guru matematika kelas X SMA Negeri 8 Batam diperoleh informasi bahwa peran guru masih sangat dominan dalam pembelajaran di kelas. Penggunaan program GeoGebra di kelas belum terlalu dikenalkan kepada siswa. Program GeoGebra merupakan salah satu media pembelajaran yang mempermudah siswa dalam mengerjakan soal berupa geometri dan aljabar serta membantu berpikir visual siswa. GeoGebra juga mempengaruhi self efficacy siswa sehingga siswa lebih percaya diri terhadap hasil yang diperoleh dari penyelesaian masalah yang diberikan melalui GeoGebra tersebut (Himmi, 2016). Informasi lain yang diperoleh adalah buku teks pelajaran yang disediakan sekolah berupa buku BOS (Buku Operasional Sekolah) tidak memuat materi sistem pertidaksamaan dua variabel sehingga siswa masih kesulitan dalam belajar mandiri di rumah. Materi sistem pertidaksamaan dua variabel merupakan salah satu kompetensi dasar pada kelas X menurut Kurikulum 2013 Edisi Revisi 2016 dan salah satu indikator yang diujikan pada Ujian Nasional (UN) menurut BSNP selama tiga tahun terakhir. Oleh karena itu, perlu dilakukan suatu upaya yang dapat mengatasi permasalahan tersebut, yaitu mengembangkan bahan ajar berupa modul pada materi sistem pertidaksamaan dua variabel dengan berbasis GeoGebra. 


\section{b. Analisis Kurikulum}

Analisis kurikulum dilakukan dengan menganalisis kompetensi inti dan kompetensi dasar serta indikator pencapaian kompetensi dengan mengacu pada Kurikulum 2013 Edisi Revisi 2016. Penelitian ini bertujuan untuk mengembangkan modul pada materi sistem pertidaksamaan dua variabel. Materi ini cocok dikembangkan dengan menggunakan program GeoGebra, karena berhubungan dengan grafik dan menentukan daerah penyelesaian dari pertidaksamaan. Program Geogebra diharapkan agar siswa lebih mudah dalam memvisualisasikan grafik dengan baik. Selain itu, program GeoGebra dapat memfasilitasi siswa dalam mengonstruksi pemahaman tentang visual terhadap benda-benda yang abstrak secara mandiri dan memeriksa kebenaran dari soal yang dikerjakan sehingga prestasi belajar matematika siswa akan meningkat.

\section{c. Analisis Karakteristik Siswa}

Berdasarkan analisis siswa tersebut, siswa kelas X memiliki kemampuan matematis yang beragam serta siswa tidak mahir dalam menggunakan teknologi yang mengalami kemajuan pesat bagi pembelajaran matematika khususnya program GeoGebra.

\section{Tahap Design (Perancangan)}

Tahap design pada penelitian ini berupa:

a. Mencari buku-buku referensi, gambar-gambar yang berkaitan dengan materi untuk digunakan dalam modul, tangkapan layar pada program geogebra.

b. Membuat garis besar isi modul berupa pengenalan program geogebra, materi pertidaksamaan linier dua variabel, pertidaksamaan kuadrat dua variabel dan materi pertidaksamaan dua variabel linier kuadrat.

c. Menyusun instrumen penelitian modul dari BNSP yang sudah dimodifikasi berupa angket yang terdiri dari 23 butir pernyataan untuk ahli materi dan 33 butir pernyataan untuk ahli media.

d. Menyusun instrument visual thinking yang diambil dari indikator : 1)mengidentifikasi dan mengklasifikasikan bagunan geometri; 2) melukis, menggambar atau menciplak bangun geometri; 3) mendeskripsikan bangun geometri secara verbal; 4) mengkonstruksi representasi visual.

e. Menyusun angket respon siswa untuk mengukur tingkat kepraktisan modul.

\section{Tahap Development (Pengembangan)}

Tahap development pada penelitian ini berupa:

a. Mengembangkan modul berbasis geogebra yang terdiri dari 3 bagian, yaitu: 1) Bagian awal terdiri dari sampul atau cover modul, identitas pemilik modul, identitas modul, kata pengantar, daftar isi, peta konsep; 2) Bagian isi terdiri dari sub judul, uraian materi, contoh, tugas, rangkuman, tes formatif, dan umpan balik; 3) Bagian penutup terdiri dari glosarium, kunci jawaban formatif, dan daftar pustaka, seperti gambar 3 berikut: 


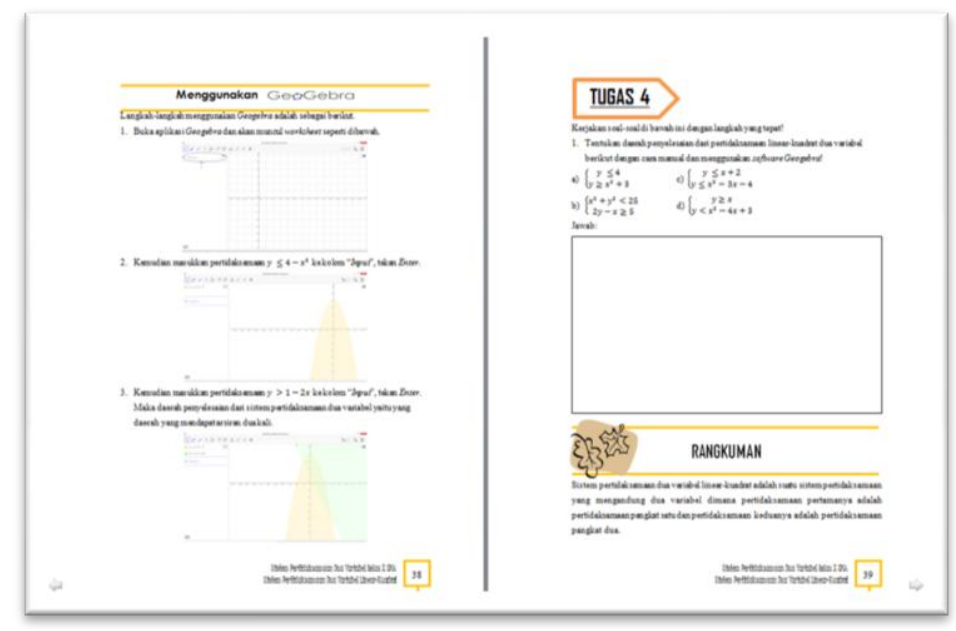

Gambar 3. Modul Berbasis Geogebra

b. Penilaian validasi modul yang terdiri 3 orang validator yaitu satu orang sebagai ahli materi dan dua orang untuk ahli media yaitu. Ketiga validator tersebut merupakan dosen dari Universitas Riau Kepulauan. Setelah dilakukan penilaian diperoleh rata-rata skor 3,26 dengan kategori valid dari ahli materi dan rata-rata skor 3,65 dengan kategori sangat valid dari ahli media, sehingga dirata-ratakan diperoleh skor 3,46 berdasarkan tabel 2 termasuk dalam kategori "Sangat Valid".

c. Revisi awal modul dilakukan setelah modul dinilai kevalidannya oleh ahli materi dan ahli media. Adapun saran dan komentar perbaikan dari ahli materi dan ahli media yang berkaitan dengan kualitas modul yang dikembangkan, mulai dari cover, bahasa hingga konten modul.

\section{Tahap Implementation}

Setelah modul dinyatakan layak diujicobakan dengan revisi oleh para ahli media dan ahli materi, maka modul dapat diimplementasikan pada pembelajaran matematika di sekolah. Implementasi dalam penelitian ini adalah proses uji coba modul berbasis GeoGebra dalam kegiatan pembelajaran. Uji coba dilakukan sebanyak 3 kali pertemuan pada siswa kelas X MIPA 5 berjumlah 38 orang di SMA Negeri 8 Batam. Peneliti memberikan modul berbasis geogebra kepada setiap siswa sehingga siswa dapat mempelajari modul dengan atau tanpa bimbingan guru di rumah. Setelah pembelajaran menggunakan modul, peneliti memberikan soal visual thinking, kemudian dihitung ketuntasan klasikal sebagai berikut:

$$
\text { ketuntasan } \begin{aligned}
(p) & =\frac{\text { jumlah siswa yang tuntas }}{\text { jumlah siswa yang mengikuti tes }} \times 100 \% \\
& =\frac{34}{38} \times 100 \%=89 \%
\end{aligned}
$$

Ketuntasan klasikal post-test yaitu $89 \%$ dengan rata-rata kelas 89,61 yang berdasarkan tabel 3 termasuk dalam kategori sangat baik. Hal ini berarti modul yang dikembangkan telah efektif yaitu modul memberikan hasil yang baik. 
Setelah diberikan soal visual thinking, siswa dminta untuk mengisi angket respon siswa untuk melihat kepraktisan modul pda proses pembelajaran, dengan perolehan nilai rerata 3,04. Berdasarkan tabel 4 hasil pengisian angket respon siswa, dapat disimpulkan bahwa modul matematika materi sistem pertidaksamaan dua variabel dengan berbantuan GeoGebra yang dikembangkan praktis yaitu modul mudah digunakan dalam kegiatan pembelajaran di sekolah.

\section{Tahap Evaluation}

Setelah uji coba selesai, peneliti melakukan evaluasi terhadap modul yang dikembangkan. Berikut kegiatan yang dilakukan pada tahap evaluasi.

a. Melakukan revisi akhir. Revisi akhir dilakukan berdasarkan hasil pengamatan selama proses uji coba di kelas. Adapun beberapa kekurangan dalam modul sehingga perlu direvisi, diantaranya: 1) Memperbaiki salah satu soal pada tugas 2 halaman 26 nomor $1 \mathrm{~b}$ karena terdapat kesalahan pengetikan dan tidak dapat difaktorkan. Awalnya sebelum direvisi $x>y^{2}-2 x+3$ diperbaiki menjadi $y>x^{2}-2 x+3$; 2) Memperbaiki salah satu soal pada tugas 4 halaman 46 nomor a bagian pertidaksamaan kuadrat dua variabel karena soal tidak dapat difaktorkan. Awalnya sebelum direvisi $y \geq x^{2}+3$ diperbaiki menjadi $y \geq x^{2}-9$.

b. Menghasilkan produk akhir yang dihasilkan adalah modul matematika materi sistem pertidaksamaan dua variabel dengan berbantuan program GeoGebra untuk siswa kelas $\mathrm{X}$ yang telah direvisi.

Berdasarkan hasil penelitian diperoleh bahwa modul geogebra memiliki rerata score kevalidan sebesar 3,46 termasuk katagori "sangat valid", rerata ketuntasan klasiskal kelas sebesar 89,61 termasuk katagori "efektif" dan rerata respon siswa sebesar 3,04 termasuk katagori "praktis". Selanjutnya pada kemampuan visual thinking siswa setelah menggunakan modul berbasis geogebra dapat dilihat pada tabel berikut:

Tabel 5. Kemampuan visual thinking siswa setelah menggunakan modul

\begin{tabular}{ccccc}
\hline No & \multicolumn{1}{c}{ Indikator } & $\begin{array}{c}\text { Rata-rata } \\
\text { Observasi }\end{array}$ & $\begin{array}{c}\text { Rata-rata } \\
\text { posttest }\end{array}$ & $\begin{array}{c}\text { Rata-rata } \\
\text { maksimal }\end{array}$ \\
\hline $1 \quad \begin{array}{l}\text { Secara verbal, siswa mendeskripsikan } \\
\text { bangun geometri dengan penampakannya } \\
\text { secara utuh }\end{array}$ & 2,42 & 3,37 & 4 \\
2 & $\begin{array}{l}\text { Mengidentifikasi dan mengklasifikasikan } \\
\text { bangun geometri berdasarkan gambar }\end{array}$ & 1,13 & 3,18 & 4 \\
\hline Jumlah rata-rata skor & 3,55 & 6,55 & 8 \\
\hline
\end{tabular}

Dari tabel 5 di atas, kemampuan visual thinking matematis siswa saat menggunakan modul berbasis GeoGebra pada materi sistem pertidaksamaan dua variabel mengalamai peningkatan. Hal ini sesuai dengan penelitian (Gumanti, 2014)dimana terdapat perbedaan kemampuan visual thinking siswa SMP yang diberikan pembelajaran scientifik menggunakan geogebra dan tanpa geogebra. Selain kemampuan visual thinking, geogebra juga dapat mempengaruhi kemampuan berpikir kritis matematis siswa (Hasibuan, 2016). 


\section{Kesimpulan}

Berdasarkan hasil penelitian dan pembahasan terhadap modul yang dikembangkan, kualitas modul pada materi sistem pertidaksamaan dua variabel berbasis GeoGebra untuk siswa kelas X SMA yang telah dikembangkan adalah sebagai berikut:

a. Ditinjau dari aspek kevalidan, yaitu penilaian oleh ahli materi dan ahli media, modul yang dikembangkan peneliti memperoleh skor rata-rata 3,46 dengan persentase pencapaian $86,5 \%$ yang termasuk dalam kategori sangat valid. Dapat disimpulkan bahwa modul yang dikembangkan valid yaitu telah sesuai dengan standar buku teks pelajaran dari BSNP serta memiliki derajat validitas sangat baik.

b. Ditinjau dari aspek keefektifan, yaitu dari tes hasil belajar (post-test) diperoleh ketuntasan klasikal tes hasil belajar yaitu $\mathbf{8 9 \%}$ yang termasuk dalam kategori sangat baik. Dapat disimpulkan modul yang dikembangkan telah efektif digunakan dalam pembelajaran matematika di sekolah.

c. Ditinjau dari aspek kepraktisan, yaitu dari hasil angket respon siswa diperoleh skor ratarata 3,04 dengan persentase pencapaian $76 \%$ yang termasuk dalam kategori baik. Dapat disimpulkan bahwa modul yang dikembangkan praktis yaitu modul mudah digunakan dalam kegiatan pembelajaran di sekolah.

d. Kemampuan visual thinking matematis siswa dengan menggunakan modul sistem pertidaksamaan dua variabel berbasis GeoGebra mengalami peningkatan, yaitu pada saat observasi diperoleh rata-rata skor 3,55 dan pada saat post-test diperoleh rata-rata skor 6,55.

\section{Daftar Pustaka}

Asngari, D. R., Keguruan, F., \& Unila, U. L. (2015). Penggunaan Geogebra dalam Pembelajaran Geometri, 299-302.

Astika, F. Fi. (2014). Pengembangan Modul Pada Materi Matriks dengan Pendekatan PMRI untuk Siswa Kelas X SMK. Skripsi. Universitas Negeri Yogyakarta.

Gumanti, sri. (2014). Pengaruh pembelajaran berbantuan Geogebra terhadap peningkatan kemampuan pemahaman dan Visual thinking siswa SMP. bandung.

Guzman, M. (2002). The Role of Visualization in Teaching and Learning of Mathematical Analysis. $\quad$ Retrieved from www.mat.ucm.es/catedramdeguzman/old/08sabormat/visualcreta/cretaversion final.pdf

Hasibuan, N. H. (2016). Perbedaan Kemampuan Berpikir Kritis Matematis Antara Pembelajaran Berbasis Masalah Berbantuan Geogebra dengan Pembelajaran Berbasis Masalah Berbantuan Autograph di MAN 1 Medan. Tabularasa, 13(1), 45-49.

Himmi, N. (2016). Perbedaan Self Efficacy Matematis Siswa Antara Pembelajaran Berbasis Masalah Berbantuan Geogebra dan Autograph di MAN 1 Medan. Pythagoras, 5(2), 165171.

Hohenwarter, M. et. a. (2004). Combination of dynamic geometry, algebra and calculus in the software 
https://archive.geogebra.org/static/publications-/pecs_2004.pdf.

Hutagalung, R. (2017). Pengembangan Perangkat Pembelajaran Model Guided Discovery Berbasis Budaya Batak Toba untuk Meningkatkan Kemampuan Pemahaman Konsep Matematis Siswa SMP. Pythagoras, 6(1), 37-52.

Ismi, I. N., \& Hidayatulloh, B. (2012). Pentingnya Visual Thinking dalam Pembelajaran Geometri SMP 1.

Kania, N. (2016). Efektivitas Penggunaan Alat Peraga Maya (Virtual Manipulative) Terhadap Peningkatan Visual Thingking Siswa. Theorems, 1(1), 45-57.

MOE. (2016). M ATHEMATICS SYLLABUS Pre-University. In Mathematics Syllabus PreUniversity (pp. 1-20).

Mohler, J. L. (2010). The Visual-Spatial System : Cognition \& Perception The Visual-Spatial p.

NCTM. (2000). Principles and Standards for School Mathematics. USA.

Pendidikan, D. (2015). Laporan Hasil Ujian Nasional. Retrieved from http://118.98.234.50/lhun/daya_serap.aspx

Sugiyono. (2016). Metode penelitian \& pengembangan research and development. bandung: Alfabeta.

Surya, E. (2012). Peningkatan Reptesentasi Visual Thingking Matematika SIswa SMPN 11 Medan dengan Melatih Keterampilan Menggambar dan Pendekatan Kontekstual. Penelitian Dan Pembelajaran Matematika, 5(1), 41-50.

Widoyoko, s eko putro. (2017). Evaluasi Program Pembelajaran. Yogyakarta: Pustaka Pelajar. 